\title{
OBITUARY
}

\section{In Memorium: Nathan Kaufman}

Laboratory Investigation (2016) 96, 1142-1143; doi:10.1038/labinvest.2016.106

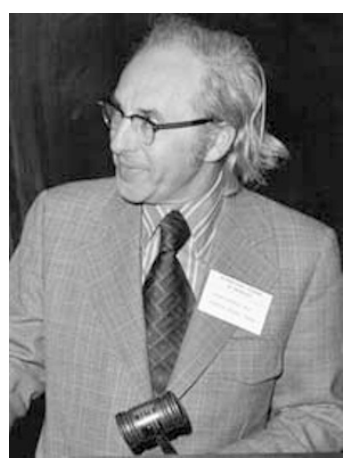

Dr Nathan Kaufman (photo: courtesy of Fred and Jean Silva. Used with permission).

North American Pathology has lost one of his luminaries, Dr Nathan Kaufman, the son of immigrants, on 11 May 2016 in Toronto. He was 100. I thank Paul Lewin at the United States and Canadian Academy of Pathology (USCAP) West and Dr David Kaminsky, USCAP's Executive Vice President, for bringing this sad news to my attention. To honor his memory, I have called upon Dr Fred Silva, former Executive Vice President of USCAP along with Dr David Hardwick, Secretariat of the International Academy of Pathology (IAP), to highlight Dr Kaufman's life. I have also had the pleasure of briefly discussing Dr Kaufman, via e-mail, with his friend and colleague Dr Samuel Ludwin and with Dr Kaufman's eldest daughter, Naomi Kaufman Price, who helped draft the original obituary that appeared in the Toronto Star. This, then, is their collective work only edited by me for style and space concerns.

Dr Kaufman was born in Lachine, Quebec, Canada on 3 August 1915 to Anna and Solomon Kaufman, a shop owner and a housepainter who had fled Riga, Latvia and Odessa, Ukraine, respectively. He overcame quotas limiting the number of Jewish students at McGill University, Montreal, Quebec, and its medical school to matriculate there first in 1937 (BS) and then in 1941 (MD and CM). He served as a captain in the Canadian Army Medical Corps from 1942 to 1945 and was honored as a Member of the Order of the British Empire, for bravery under fire.

After the war, he trained in Pathology at the Royal Victoria Hospital and Jewish General Hospital, Montreal, and then the
Cleveland City Hospital, Cleveland, Ohio. He met Rita Friendly, a radiology technician, and they married in 1946. Their relationship was one of respect, devotion, and shared intellectual and cultural pleasures, and sheer love until her death in 2006.

Nate, as he was known to his friends, began his academic career in 1948 as an Instructor, rising through the ranks of Assistant Professor to Associate Professor of Pathology, all at the then Western Reserve Medical School, Cleveland, OH. He joined the International Academy of Medical Museums (IAMM) in 1949. From 1960 to 1967 he was Professor of Pathology, Duke University School of Medicine, Durham, NC. In 1967 he and his family moved to Kingston, Ontario, where (through 1981) he was Professor and Head of the Department of Pathology, Queen's University at Kingston, Ontario. He became President of the United States and Canadian Division of the IAP in 1973-1974 and of the IAP from 1976 to 1978.

Upon becoming the first full-time Secretary-Treasurer of the United States and Canadian Academy of Pathology in 1979-1991, he saw to the incorporation of USCAP (also the United States and Canadian Division of the IAP) separately from the IAP with its own Constitution, Bylaws and Affiliation agreement with the IAP. He also became (from 1979 to 1985) Clinical Professor, Office of Humanities, Medical College of Georgia, Augusta, GA. He and Rita returned to Kingston in 1994 and after Rita's death in 2006 Nate moved to Toronto.

Nate's research focused on iron metabolism, and his colleagues spoke of him as a major force in the improvement of pathology research and clinical work and of his meticulous and evenhanded leadership and mentorship. Other selected career highlights include Chairman, Association of Chairmen of Pathology Departments of Canadian Medical Schools; Senate of Queen's University; Chairman, Grants Committee for Pathology and Morphology, Canadian Medical Research Council; Chairman, Intersociety Pathology Council and Pathology Section Council of the American Medical Association. He received the Distinguished Alumni Award from Duke University in 1975.

In 1967 Dr Kaufman became Associate Editor, American Journal of Pathology. He was also the Founding Associate 
Editor of Laboratory Investigation (1950-1966) and its Editor (1972-1975). He also was Founding Editor of Modern Pathology (1988) and Series Editor, IAP Monographs in Pathology (1980-1991).

He served the third longest term of any Secretary-Treasurer of the IAP/USCAP (after Maude Abbott and Kash Mostofi), as well as the first full-time Secretary of the IAP/USCAP. He established the Secretariat with appropriate office space and headed the construction of the USCAP office in Augusta, GA. In 1996, the first year they were given, he received the IAP Gold Medal for outstanding contributions to IAP education and research. In March 2000, the USCAP honored him by the establishment of the Nathan Kaufman Timely Topic Lecture at the USCAP Annual Meeting. Nate was known for his keen sense of judgment in assessing the strengths of others and thus carefully recruited pathologists to numerous committees and position in the IAP/USCAP. He was very detailed on his ideas on the education of pathologists locally (Canada and US) as well as globally. He solicited opinion widely and then proceeded to implement those broadly accepted programs.

Dr Kaufman lived a full life and leaves children Naomi (Steve), Michael (Betty), Miriam (Roberta), Hannah (Mary), and Judith (Neil); grandchildren Liam (Lisa), Jacob, Aviva, Jazz, and Chloe; and great-grandchildren Nathan, Jaxen, Gemma, and Grant; as well as friends and relatives he cared deeply about. His sister and brother died earlier.To the end he delighted in life. He established the Dr Nathan Kaufman Service-Learning Fund at Queen's University to assist medical and health-sciences students to engage in community service to learn about the importance of justice and equity when working with vulnerable populations. Even in his last year he was fully supportive of the IAP and made a sizable donation to its Foundation.

If you seek his monument, look about you in all the various contributions he made to our specialty, and all those we serve - our patients, our students, our physicians. He will be missed greatly. What he put in place will not and will continue for generations to come.

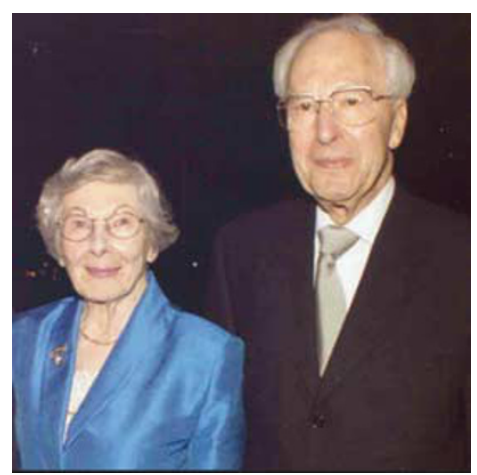

Dr and Mrs Nathan Kaufman (photo: courtesy of Fred and Jean Silva. Used with permission).

Gene P Siegal, Editor-in-Chief 